\title{
Evaluation of the Third Class Science Text Book from the Teacher's Perspective at Madaba Municipality
}

\author{
Osama M. Kraishan ${ }^{1} \&$ Ismail Almaamah ${ }^{1}$ \\ ${ }^{1}$ Alhussain Ben Talal University, Jordan \\ Correspondence: Osama M. Kraishan, Alhussain Ben Talal University, Jordan. E-mail: okraishan@yahoo.com
}

Received: August 12, 2015

Accepted: September 13, 2015 Online Published: February 25, 2016

doi:10.5539/ies.v9n3p123

URL: http://dx.doi.org/10.5539/ies.v9n3p123

\begin{abstract}
This study aimed at evaluating the science textbook of the third grade primary school in Jordan from the point of view of the teachers who have taught this textbook, in order to find out how suitable and relevant this textbook is to the structure of the curriculum and its guidelines, by trying to answer this question: What is the evaluation of science textbook of the third grade from the standpoint of science teachers in the following aspects: general appearance, the book's introduction, content of the book, aids and activities in the book, the contribution of the book to the development of students' attitudes toward science, evaluation methods contained in the book, the appropriateness of the number of weekly classes to the content of the book, the availability of laboratories and the necessary materials to carry out activities, and finally the language of the book. The study population consisted of all 110 science teachers in governmental schools in Madaba who have taught the science textbook. While The study sample consisted of (51) teachers who were selected randomly, then the researchers prepared a questionnaire as an instrument for their study consisting of (62) paragraphs displayed by a number of arbitrators and specialists for the sake of verifying its validity and reliability, and it covers nine aspects. Results related to study main question showed that the total score of teachers evaluating for science textbook of the third grade was high as the percentage reached (70.6), and this is evident that the Jordanian experience in curriculum development and design is a rich experience and with high level, parallel with the experiences of other countries. Finally, the researchers recommend that science teachers and their supervisors should necessarily take part in designing the science textbook because they are only the ones who work with it. They also recommend that more studies on science textbooks should be done for the sake of the development of its curriculums.
\end{abstract}

Keywords: evaluation, science textbook, third class

\section{Introduction}

\subsection{Introduction of the Problem}

What should science education aim at? Our engagement with this question takes us first to the more general question: what is the basic goal of education?

Science and technology are constantly transforming our day-to-day living. Science education has become of vital importance to prepare learners for this ever-changing world. Unfortunately, science education in South Africa is hampered by under-qualified and inexperienced teachers. Textbooks of good quality can assist teachers and learners and facilitate the development of science teachers. For this reason, thorough assessment of textbooks is needed to inform the selection of good textbooks. An investigation revealed that the available textbook evaluation instruments are not suitable for the evaluation of the physical science textbooks in the South African context. An instrument is needed that focuses on science education textbooks and which prescribes the criteria, weights, evaluation procedure and rating scheme; and that can ensure justifiable, transparent, reliable and valid evaluation results. This study utilized elements from the Analytic Hierarchy Process (AHP) to develop such an instrument and to verify the reliability and validity of the instrument's evaluation results.

To be brief, we can do no better than quote Gandhi: "True education is that which draws out and stimulates the spiritual, intellectual and physical faculties of the children". Implicit in this aim is the belief (that we share) that education has the potential to transform individuals and societies. What then are we looking for, as we particularize our thoughts on science education? Clearly, any discussion of the aims of science education presupposes a view of science, its methods, scope and limitations. Before we dwell on science education, we 
must, therefore, briefly comment on the nature of science.

The processes and ideas of science are of great importance to everybody in three ways. The first is in their personal lives, for example, so that they can validly identify the components of a healthy life-style. The second is in their civic lives, so that they can take an informed part in social decisions, like on future options for electricity supply. The third is in their economic lives, where they need to be able to respond positively to changes in the science-related aspects of their employment.

What analysis and evidence are available to help promote high quality science education for all future citizens? There must be a greater recognition of what students bring to their studies and how different teaching methods engage with their learning. The diversity in students' learning strategies must be met by the use of suitable teaching methods. The curriculum must be closely matched to the purposes of 'science education for citizenship'. The assessment of what has been learned must be closely matched to the purposes of that curriculum. And, central to all of these aims, the supply, development, and retention of high quality teachers must be actively pursued.

About 40 years ago science education came to be recognized around the world as an independent field of research. The concerns of this research are distinct from the concerns of science and those of general education. Its methods and techniques were initially borrowed from the sciences, but new methods are being developed suited to the research questions. Motivation for this research comes from the need to improve the practice of science education. We begin by asking, which methods of teaching work better than others? Studies in the 1970s typically compared experimental classrooms with controls.

Motivation for this research comes from the need to improve the practice of science education. New teaching aids were tried out; lecture methods were compared with activity-based teaching, and so on.

The need for curriculum Reform in Science Education in Jordan has begun to influence the general education atmosphere everywhere, then to do something about the development of a new science teaching curriculum for schools. We hope that this is the beginning of a long and important process in where there are discussing comments, criticisms and suggestions on the content of our work; thus, we may improve upon it in the future.

The curriculum is considered the core element of the education process in which we get our nation goals and expectations, and it is an interpretation of the education philosophy existing in the society, and it also reflects the policy lay down by the state.

The development of curricula is one of the most critical educational matters, because the development of a curriculum involves all the cultural dimensions that in somehow will identify the nation characteristics, the culture of the community, and the characteristics of its members.

The curriculum links between the changes in the field of science and technology, plus the community uses of these changes. In fact, we do not exaggerate if we say that the difference between the developed countries and underdeveloped countries lies in the quality of the curriculum provided to their members of the community (Ibrahim, 2000).

Curriculum is an important issue raised around controversy and debate among educators, politicians, economists and sociologists, where the blame lies on curriculum whenever a country suffers from vulnerability at the moral and national levels, or with the lack of production, or even any other negative social phenomena.

The textbook is a mainstay of the pillars of the educational process where researchers, educators and organizers of the educational process consider it as an important contributing factor in determining the appropriate subject for all pupils according to age and grade (Abu Ali, 1989).

\subsection{Importance of the Study}

This study gains its importance from the importance of developing any textbook in general, and the importance of science in particular, and the importance of this study emerges as it is reflecting the views of the science teachers who have taught this science textbook for the third primary grade classes in various fields, especially since these teachers are the ones who have dealt with this textbook and with the students who have been studying this textbook.

And of course the importance of this study increases if we know that this textbook is a new publication for the third grade students in the primary schools of Jordan. Therefore, the researchers hope that the results of this study will be of great benefit to the various private educational institutions to detect deficiencies, if any. 


\subsection{Relevant Scholarship}

Advancement of the Instrument for the Evaluation of Science Education Textbooks started with the definition of criteria. Attributes that impact the nature of course books were distinguished from writing, existing assessment instruments and partners' worries. These qualities or criteria were partitioned into classes or branches to give a various leveled structure. Subject specialists confirmed the substance legitimacy of the progression.

Master science educators thought about the significance of diverse criteria. The information was utilized to infer weights for the distinctive criteria with the Expert Choice PC application. A rubric was detailed to go about as an evaluating plan and a score sheet. Amid the course reading assessment prepare the appraisals were exchanged to a spreadsheet that figured the scores for the nature of a reading material all in all and for the distinctive classes. The instrument was tried on little scale, balanced and after that connected on a bigger scale. The aftereffects of diverse investigators were contrasted with confirming the unwavering quality of the instrument. Triangulation with the feelings of instructors who have utilized the reading material affirmed the legitimacy of the assessment results acquired with the instrument. Future examinations on the assessment instrument can incorporate the utilization of diverse rating scales and restricting of criteria.

The discriminating investigation of science course readings is fundamental in enhancing, showing and learning at all levels in the subject. And this volume sets out a scope of scholastic points of view on how that examination ought to be finished; every part concentrates on a part of science course reading examination, with scope of everything from hypothetical and philosophical underpinnings, methodological issues, and reasonable structures for discriminating investigation, to handy strategies for assessment.

Science course readings are essential sources utilized by science instructors all through the world to guide them in showing the substance and abilities endorsed in the curricula (Chiappetta, 1991; Hubisz, 2003; Leite, 1999; Stoffels, 2005).

Teachers and also learners spend a lot of their planning; class also, homework time working with course book materials (Nicol \& Crespo, 2006, p. 331). Course readings are relied upon to give a structure to what is taught, how it might be taught and in what grouping it can be taught. Of the numerous components, which advance or impede science taking in, the reading material is a standout amongst the most discriminating (Leite, 1999; Hubisz, 2003).

Numerous center school instructors in the United States of America (USA) do not have adequate preparing in physical science (Hubisz, 2003). The circumstance is comparative in South Africa (Stoffels, 2005). Reading material can be particularly useful to the unpracticed instructor (Dreckmeyr et al., 1994). A decent reading material can help these instructors to keep in front of the vast majority of their learners and learn as they go (Hubisz, 2003). In any case, teachers ought to be sufficiently adaptable to break far from the course reading presentation to answer questions from excited learners or give more illustrations and clarifications to help those that battle.

South African instructors are required to plan and create learning materials as per the needs of their learners (Department of Education, 1998). Rogan (2004) found that not very many teachers could do this. Subsequently they decided on educational program adjusted bolster material that was economically arranged (Stoffels, 2005).

Constructivism is the most by and large acknowledged ideal model utilized as a part of instruction today. A key part of this hypothesis is that learning about the outside world is seen as human development (Duit \& Treagust, 2003). Learning is therefore not saw as an exchange of information, but rather that learners are effectively building or making their insight, taking into account their encounters and existing information.

Learning may happen through the expansion of information to current ideas, formation of new ideas, or real adjustment of current ideas (Bybee, 2002). This procedure of building importance is installed in a specific social setting of which the learner is part (Ensor et al., 2002; Duit \& Treagust, 2003).

Through the procedure of significant learning (Ausubel, 1963), guideline

Characteristic sciences course readings 177 should expand on learners' former information (i.e. their current ideas and predispositions) looking to coordinate new learning into their intellectual structures (Novak, 2004). In this way, the former learning and particularly the option originations that learners convey to the classroom ought to be taken into record before new ideas are presented. In science instruction elective originations are seen as thoughts that are conflicting with the current investigative importance (Thijs \& Van nook Berg, 1995) and are thusly respected as non-investigative. A few option originations of the idea of warmth have been accounted for in writing (Erickson \& Tiberghien, 1989; Driver et al., 1994; Leite, 1999), e.g. warmth is a liquid, a substance, vitality controlled by an object, or the same as temperature. 
The constructivist ideal model demonstrates criteria for the movement and presentation of the experimental substance in course books. Tarr et al. (2006) examine three key measurements that give a general system to inspecting and selecting science course books, to be specific, content accentuation, instructional center and educator support. These measurements can just as well be connected to the determination of science course books. The main system stresses the substance what's more, incorporates arrangement with the learning desires exhibited in the educational module, top to bottom presentation of themes with expanding refinement crosswise over evaluations, and a suitable parity of aptitudes improvement and comprehension of ideas and procedures. Dreckmeyr et al. (1994), Leite (1999), and Hubisz (2003) anxiety the accompanying criteria: experimental exactness, treatment of elective originations, theoretical improvement, suitable level of presentation, what's more, suitable ordinary uses of the substance.

The second system of Tarr et al. (2006) for reading material choice is instructional center. This incorporates that exercises ought to cultivate the improvement of science as a human try and a state of mind, that learners ought to share their thoughts and that request, reflection, discriminating considering, problem-solving, what's more, appearing well and good ought to be advanced. Dreckmeyr et al. (1994) includes that exercises ought to be intriguing and identify with learners' encounters.

Exercises ought to connection learners' pre-information with investigative information. In Venture 2061 (AAAS, 2006), the investigators searched for the accompanying instructional attributes in the books they assessed (Roseman et al., 1999), in particular, whether the books

- Alarmed teachers to ordinarily held learner thoughts,

- Gave learners a mixture of phenomena,

- Guided learner elucidation and thinking,

- Gave rehearse in utilizing logical thoughts, and

- Exhibited the utilization of learning.

With respect to instructor bolster (their third system) the inquiry to be addressed was whether the course book upgraded the nature of direction (Tarr et al., 2006). As per Leite (1999), course reading journalists ought to make their pedagogical suppositions express in teacher guides. They ought to clarify the "how" and "why" of a course reading's association. Aside from appraisal instruments, activities and ventures, course books ought to give chances to educators.

\subsection{Questions of the study}

What is the evaluation of science textbook of the third grade from the standpoint of science teachers in the following aspects: general appearance, the book's introduction, content of the book, aids and activities in the book, the contribution of the book to the development of students' attitudes toward science, evaluation methods contained in the book, the appropriateness of the number of weekly classes to the content of the book, the availability of laboratories and the necessary materials to carry out activities, and finally the language of the book?

\section{Method}

This study aimed at evaluating science textbook for third grade from the viewpoint of teachers in the province of Madaba, and this chapter contains a description of the study population, the selection of the sample, the steps needed to build a study instrument, verification of validity and reliability, a description of the procedures for the study design, and finally statistical methods used to analyze the results.

\subsection{Study Methodology}

The researchers used the descriptive analytical method for the purpose of research.

\subsection{Study Population}

The study population consisted of all (110) teachers in governmental schools in Madaba who have taught science textbook for primary third grade.

\subsection{Study Sample}

The study sample is a simple random sample selected by giving all teachers a number from (1 to 110), and then the sample was selected number of members (51) teachers through the program figures randomness provided by the program, Microsoft Excel, and divided the study sample as shown in the Table 1. 
Table 1. The distribution of the sample according to the variables of gender, qualification

\begin{tabular}{|c|c|c|c|c|}
\hline No. & & Variables & Repetition & Percentage $\%$ \\
\hline 1 & \multirow{3}{*}{ Gender } & Male & 24 & 47.7 \\
\hline 2 & & Female & 27 & 52.9 \\
\hline 3 & & Bachelor & 9 & 17.6 \\
\hline 4 & \multirow[t]{2}{*}{ Qualification } & Diploma + Bachelor & 38 & 74.5 \\
\hline 5 & & Master degree or higher & 4 & 7 \\
\hline
\end{tabular}

\subsection{Study Instrument}

The researchers prepared a questionnaire for the purposes of research, they have used more than one source of intake calendar textbooks during the drafting of the paragraphs of the questionnaire, including:

- Evaluation Form textbook approved by the Ministry of Education of Jordan.

- Conducting interviews with science teachers who teach the textbook.

The resolution of its final form consisted of (62) paragraph, has been distributing these paragraphs on nine fields to evaluate the science textbook for third grade as in the Table 2:

Table 2. Evaluate the science textbook for third grade

\begin{tabular}{|c|c|c|}
\hline No. & Field & Paragraphs numbers \\
\hline 1 & general appearance of the book & 8 \\
\hline 2 & Introduction & 6 \\
\hline 3 & The content & 10 \\
\hline 4 & Activities and methods & 9 \\
\hline 5 & $\begin{array}{l}\text { The development of students' attitudes toward the book of science and } \\
\text { scientists }\end{array}$ & 8 \\
\hline 6 & The book questions and Calendar methods & 9 \\
\hline 7 & Appropriateness of the number of lectures with the content of the book & 4 \\
\hline 8 & $\begin{array}{l}\text { Appropriateness of activities and experiences, the potential of the school } \\
\text { and the surrounding environment. }\end{array}$ & 4 \\
\hline 9 & Language purpose & 4 \\
\hline 10 & Total & 62 \\
\hline
\end{tabular}

\section{Results}

\subsection{Results Related to the Study Question}

To answer this question the arithmetic means and the standard deviations and the percentages are used to determine the degree in order to evaluate teachers in field of science textbook.

\subsection{General Appearance of the Book}

Arithmetical averages and standard deviations and percentages were extracted to determine the degree of evaluating teachers general for appearance of the book, and Table 3 shows the results:

Table 3. Arithmetical averages and standard deviations and percentages of teachers on field estimates the general appearance of the book

\begin{tabular}{llcccr}
\hline No. & Introduction field & $\begin{array}{c}\text { Arithmetic } \\
\text { means }\end{array}$ & $\begin{array}{c}\text { Standard } \\
\text { deviation }\end{array}$ & Percentage & Level \\
\hline 1 & General appearance of the book & 3.27 & 0.85 & 65.5 & Medium \\
\hline
\end{tabular}




\begin{tabular}{llllll}
\hline 2 & the cover of the book is remarkable & 3.18 & 1.05 & 63.5 & High \\
3 & $\begin{array}{l}\text { There is an introduction for each unit at the } \\
\text { beginning }\end{array}$ & 3.47 & 0.81 & 69.4 & Medium \\
$4 \quad \begin{array}{l}\text { Including guiding for student } \\
5\end{array} \quad \begin{array}{l}\text { Excite the learner provided motivation for the } \\
\text { study of subjects of the book }\end{array}$ & 4.37 & 0.77 & 67.5 & High \\
$6 \quad \begin{array}{l}\text { provided general ideas relating to a substance } \\
\text { book }\end{array}$ & 3.98 & 0.55 & 79.6 & High \\
$7 \quad \begin{array}{l}\text { submitted by the science book to contribute the } \\
\text { calendar }\end{array}$ & 4.04 & 0.69 & 80.8 & High \\
$8 \quad$ General degree & 3.25 & 0.76 & 71.8 & Medium \\
\hline
\end{tabular}

\subsection{The Introduction}

Arithmetic means, standard deviations and percentages was extracted to determine the degree of evaluating teacher's paragraphs field introduction to the book, and Table 4 shows the results:

Table 4. Arithmetic averages, standard deviations and percentages of teachers on field estimates introduction to the book

\begin{tabular}{|c|c|c|c|c|}
\hline Introduction field & $\begin{array}{l}\text { Arithmetic } \\
\text { means }\end{array}$ & $\begin{array}{l}\text { standard } \\
\text { deviation }\end{array}$ & Percentage & Level \\
\hline $\begin{array}{l}\text { The book is a modern scientific commensurate with } \\
\text { the scientific development }\end{array}$ & 4.06 & 0.83 & 81.2 & High \\
\hline $\begin{array}{l}\text { Scientific material of the book appropriate to } \\
\text { achieve the objectives }\end{array}$ & 3.90 & 0.90 & 78.0 & High \\
\hline $\begin{array}{l}\text { The scientific material is appropriate to the mental } \\
\text { abilities of the students }\end{array}$ & 3.29 & 0.90 & 65.9 & Medium \\
\hline $\begin{array}{l}\text { The scientific material of the book is related to the } \\
\text { daily life of the student. }\end{array}$ & 3.71 & 0.92 & 74.1 & High \\
\hline $\begin{array}{l}\text { The scientific material The book is concerned to } \\
\text { guide to the student in choosing a career related to } \\
\text { science }\end{array}$ & 2.71 & 1.03 & 54.1 & Medium \\
\hline $\begin{array}{l}\text { The scientific material of the book Take into } \\
\text { individual differences among students }\end{array}$ & 2.82 & .95 & 56.5 & Medium \\
\hline $\begin{array}{l}\text { At the end of each unit is a appropriate summery } \\
\text { helping in increasing the understanding for the unit }\end{array}$ & 3.65 & 1.28 & 72.5 & High \\
\hline $\begin{array}{l}\text { The Examples contained in the book is enough to } \\
\text { strengthen the student's understanding of the } \\
\text { scientific material of the book }\end{array}$ & 3.41 & .94 & 68.2 & Medium \\
\hline $\begin{array}{l}\text { The book is based on scientific information and } \\
\text { previous experience of the student received in the } \\
\text { previous grades }\end{array}$ & 3.63 & .82 & 72.5 & High \\
\hline $\begin{array}{l}\text { The book includes scientific material in different } \\
\text { fields of science (physics, chemistry, biology) }\end{array}$ & 4.43 & .64 & 88.6 & High \\
\hline Total score & 3.56 & & 71.2 & High \\
\hline
\end{tabular}

\subsection{Activities and the Methods Contained in the Book}

Arithmetic averages and standard deviations and percentages were extracted to determine the degree of 
evaluating teacher's paragraphs field activities and methods contained in the book, and Table 5 shows the results:

Table 5. Arithmetic averages, standard deviations and percentages of teachers on estimating activities field and the methods in the book

\begin{tabular}{|c|c|c|c|c|c|}
\hline No. & Field of activities & $\begin{array}{l}\text { Arithmetic } \\
\text { means }\end{array}$ & $\begin{array}{l}\text { standard } \\
\text { deviation }\end{array}$ & Percentage & level \\
\hline 1 & $\begin{array}{l}\text { Possibility of having variety of } \\
\text { methods in teaching the books' } \\
\text { scientific content }\end{array}$ & 4.33 & 0.68 & 86.7 & High \\
\hline 2 & $\begin{array}{l}\text { The experiments and activities in the } \\
\text { book are compatible with its scientific } \\
\text { content }\end{array}$ & 4.04 & 0.72 & 80.8 & High \\
\hline 3 & $\begin{array}{l}\text { The proposed activities are reliable } \\
\text { and possible to do }\end{array}$ & 3.84 & 0.81 & 76.9 & High \\
\hline 4 & $\begin{array}{l}\text { The methods of the book are } \\
\text { compatible with the subjects in it }\end{array}$ & 3.71 & 0.67 & 74.1 & High \\
\hline 5 & $\begin{array}{l}\text { There are enough instructions for the } \\
\text { activities to get it possibly done }\end{array}$ & 3.80 & 0.85 & 76.0 & High \\
\hline 6 & $\begin{array}{l}\text { The suggested activities are possible } \\
\text { for the student to do }\end{array}$ & 3.67 & 0.82 & 73.3 & High \\
\hline 7 & $\begin{array}{l}\text { The activities are suitable for the } \\
\text { needs of the students }\end{array}$ & 3.24 & 0.79 & 64.7 & Average \\
\hline 8 & $\begin{array}{l}\text { The students are able to do the } \\
\text { activities by themselves }\end{array}$ & 3.14 & 0.85 & 62.7 & Average \\
\hline 9 & $\begin{array}{l}\text { The activities and methods achieve } \\
\text { their scientific goals }\end{array}$ & 3.76 & 0.71 & 75.3 & High \\
\hline \multicolumn{2}{|c|}{ Total score } & 3.73 & & 74.5 & High \\
\hline
\end{tabular}

\section{Discussion}

Results related to study main question showed that the total score of teachers evaluating for science textbook of the third grade was high as the percentage reached (70.6), and this is evident that the Jordanian experience in curriculum development and design is a rich experience and with high level, parallel with the experiences of other countries.

As for the aspects of evaluating various authors, the results showed that the general appearance of the book, the book's content, the aids and the activities in the book, the contribution of the book to the development of students' attitudes toward science, and the field of media were highly appreciated; while the introduction to the book, the appropriateness of the number of shares of the content, the appropriateness of activities and experiences for the potential of the school and the surrounding environment with the average estimate, the researcher believes that the team authoring did not give an importance to the introduction, and the book based on what is in the surrounding environment, or because it has been the adoption of authors from outside Madaba, and can also be attributed to the lack of involvement of teachers and parents in writing the book.

\section{Acknowledgments}

I would like to express my gratitude and thanks to those who helped me in doing this study. In fact, it was my pleasure to deal with and learn from all of them throughout the period of time the study was being conducted. Again, members of the sample are highly appreciated for their time and effort offered to answer the study instruments.

\section{References}

Driver. R., Squires, A., Rushworth, P., \& Wood-Robinson, V. (1994). Making sense of secondary science: Research into children's ideas. New York: Routledge. 
Duit, R., \& Treagust, D. F. (2003). Learning in science-From behaviourism towards social contsructivism and beyond. In B. J. Fraser, \& K. G. Tobin (Eds.), International handbook of science education. Dordrecht: Kluwer academic press.

Edwards J. M. (2007). Evaluering van natuurwetenskaphandboeke vir die onderrig van warmte in graad 7. MEd-verhandeling. Potchefstroom: Noord-Wes Universiteit.

Ensor, P., Dunne, T., Galant, J., Gumedze, F., Jaffer, S., Reeves, C., \& Tawodzera, G. (2002). Textbooks, teaching and learning in primary mathematics classrooms. African journal of research in SMT education, 6 , 21-35.

Erickson, G., \& Tiberghien, A. (1989). Heat and temperature. In R. Driver, E. Guesne, G. L. Erickson, \& A. Tiberghien (Eds.), Children's ideas in science. Philadelphia: Milton Keynes.

Hubisz, J. (2003). Middle-school texts don't make the grade. Physics today, 50-54. http://dx.doi.org/10.1063/1.1583534

Knight, R. D. (2004). Physics for scientists and engineers. A strategic approach. San Francisco: Pearson Addison Wesley.

Kulm, G., Roseman, J., \& Treistman, M. (1999). A benchmarks-based approach to textbook evaluation. Science books and films, 35. Retrieved from http://www.project2061.org/publications/textbook/articles/approach. htm

Lawson, A. E. (1999). What should students learn about the nature of science and how should we teach it? Applying the "If-and-then-therefore" pattern to develop students' theoretical reasoning abilities in science. Journal of college science teaching, 28, 401-411.

Leedy, P. D., \& Ormrod, J. E. (2005). Practical research: Planning and design (8th ed.). Upper Saddle River: Pearson Education.

Leite, L. (1999). Heat and temperature: an analysis of how these concepts are dealt with in textbooks. European journal of teacher education, 22, 75-88. http://dx.doi.org/10.1080/0261976990220106

Lemmer, M., \& Edwards, J. M. (2007). Evaluation of natural sciences textbooks. Paper presented at the SAIP conference, WITS University, Johannesburg, 2-5 July.

McKinney, D., \& Michalovic, M. (2004). Teaching the stories of scientists and their discoveries. The science teacher, 46-51.

National Science Teacher's Association (NSTA). (2005). The use and adoption of textbooks in science teaching. Retrieved August 13, 2005, from http://www.nsta.org/textbooks

Nicol, C. C., \& Crespo, S. M. (2006). Learning to teach with mathematics textbooks: How preservice teachers interpret and use curriculum materials. Educational studies in mathematics, 62, 331-355. http://dx.doi.org/10.1007/s10649-006-5423-y

Novak, J. D. (2004). Reflections on a half-century of thinking in science education and research: Implications from a twelve-year longitudinal study of children's learning. Canadian journal of science, mathematics and technology, 4, 23-41. http://dx.doi.org/10.1080/14926150409556595

\section{Copyrights}

Copyright for this article is retained by the author(s), with first publication rights granted to the journal.

This is an open-access article distributed under the terms and conditions of the Creative Commons Attribution license (http://creativecommons.org/licenses/by/3.0/). 